\title{
DIMENSI TEKS WACANA KRITIS MODEL VAN DICK DALAM SYAIR NASEHAT DINIYAH KARYA HASAN QOLAY
}

\author{
Dedy Mardiansyah ${ }^{1 *}$, Yandi $^{2}$, Lailatul Fitriyah ${ }^{3}$ \\ Program Studi Pendidikan Bahasa dan Sastra Indonesia \\ STKIP Nurul Huda OKU Timur \\ banged@stkipnurulhuda.ac.id \\ lailatul@stkipnurulhuda.ac.id
}

\begin{abstract}
Abstrak
Penelitian ini bertujuan untuk mendeskripsikan Struktur teks Nasehat Diniyah dalam kitab Taudihus Sholah karya Hasan Qolay dengan menggunakan teori wacana kritis model Van Dijk yang meliputi struktur makro, superstruktur, dan struktur mikro. Metode yang digunakan dalam penelitian ini adalah metode kualitatif deskriptif. Data dalam penelitian ini adalah kata-kata dalam teks syair Nasehat Diniyah kitab Taudihus Sholah. Data diambil dengan teknik simak dan catat. Berdasarkan hasil analisis dapat dinyatakan bahwa dimensi teks model analisis wacana kritis Van Dijk pada teks syair Nasehat Diniyah (ND) pada analisis aspek struktur makro ditemukan bahwa tema syair ND adalah ajakan untuk senantiasa mengingat akhirat dengan menegakkan sholat sebelum kematian datang. Pada analisis super struktur (skematik) ditemukan bahwa teks syair ND terdiri dari pembukaan, isi, dan penutup. Teks syair diawalai dengan bait pembuka yang berupa permintaan maaf dari penulis. Pada bagian isi, teks syair berisi bait-bait tentang anjuran untuk senantiasa mengingat akhirat dengan cara senantiasa menjaga sholat lima waktu. Selain itu pada bagian ini penulis juga mengungkapkan peringatan akan datangnya kematian yang bisa muncul kapan saja. Pada bagian penutup, penulis syair menegaskan tentang kewajiban untuk menegakkan perintah dan menghindari larangan dalam agama dengan harapan Tuhan akan memberikan pungkasan kehidupan yang baik (meninggal dalam keadaan khusnul khotimah). Pada bagian unsur struktur mikro, latar penulisan teks syair adalah masyarakat desa Campang Tiga.
\end{abstract}

Kata Kunci: Nasehat Diniyah, Dimensi teks, Teun Van Dijk.

\section{PENDAHULUAN}

Bahasa merupakan alat komunikasi yang memiliki peranan penting dalam interaksi antar manusia. Dengan bahasa manusia dapat menyampaikan berbagai keperluan dan tujuannya. Menurut Kridalaksana (2008:24), bahasa adalah sistem lambang bunyi yang digunakkan oleh anggota kelompok sosial untuk bekerja sama, berkomunikasi, dan mengidentifikasi diri. Arbitrer pada bahasa inilah yang mampu memberikan suatu warna tersendiri dari bahasa yang menjadi ciri khas atau indentitas sebuah suku daerah. Bahasa digunakan oleh manusia sebagai alat untuk mertukar informasi atau pikiran. Dengan bahasa semua orang dari belahan dunia manapun dapat saling berkomunikasi dan saling mengenal satu sama lain. Pateda (dalam Humaira, 2018:32) memaparkan bahwa bahasa adalah media yang ampuh untuk mengkoneksikan dunia seseorang dengan apa yang ada di luar dirinya.

Sebagai media penyampai pesan, bahasa dikemas dalam wacana yang sedemikian rupa agar pesan yang hendak disampaikan kepada pembaca dapat diterima dengan baik. Untuk kepentingan tersebut bahasa dikemas menjadi wacana yang utuh dan menarik. Berkaitan dengan wacana, Darma (2009:03) memaparkan bahwa "Wacana merupakan rangkaian ujar atau rangkaian tindak tutur yang mengungkapkan suatu hal yang disajikan secara teratur, sistematis, dalam satu kesatuan koheren, yang dibentuk oleh unsur-unsur segmental dalam sebuah wacana besar.

Untuk memahami pesan dalam sebuah wacana, perlu melakukan analisis wacana secara mendalam. Analisis dapat dilakukan tidak hanya sebatas analisis wacana secara umum, namun harus dengan pendekatan analisis wacana kritis. Darma (2009:51) menjelaskan bahwa dalam analisis wacana kritis (AWK), wacana tidak semata-mata dipahami sebagai studi bahasa. Pada akhirnya, memang analisis wacana kritis menggunakan bahasa dalam teks yang dianalisis, tetapi bahasa yang dianalisis dalam AWK berbeda dengan studi bahasa dalam pengertian linguistik tradisional. Bahasa yang dianalisis oleh AWK bukan mengambarkan aspek bahasa saja, tetapi juga menghubungkannya dengan konteks.

Teks syair pada penelitian ini akan dianalisis menggunakan teori wacana kritis model Van Dick 
DIMENSI TEKS WACANA KRITIS MODEL VAN .... $\mid 21$ yaitu difokuskan pada dimensi teks. Kerangka analisis wacana kritis model Van Dijk meliputi tiga dimensi, yaitu dimensi teks, dimensi kognisi sosial, dan dimensi konteks sosial. Dimensi teks berkaitan dengan tingkatan atau struktur yang membangun teks. Dalam hal ini Van Dijk membaginya menjadi tiga tingkatan, yaitu struktur makro, superstruktur, dan struktur mikro. Struktur makro berkaitan dengan makna global dari suatu teks yang dapa diamati dari topik atau tema teks. Super struktur berkaitan dengan kerangka teks yang terdiri atas pendahuluan, isi, penutup, dan simpulan. Struktur mikro merupakan makna lokal yang terdiri atas pilihan kata, kalimat, dan gaya bahasa yang dipakai pada suatu teks (Eriyanto, 2011:227).

Tabel 1

Struktur Teks Van Dijk

\begin{tabular}{|l|l|}
\hline Struktur Makro & $\begin{array}{l}\text { Makna global dari suatu teks yang dapat diamati dari topik } \\
\text { atau tema yang diangkat oleh suatu teks }\end{array}$ \\
\hline Superstruktur & $\begin{array}{l}\text { Kerangka suatu teks: bagaimana struktur dan elemen wacana } \\
\text { disusun dalam teks secara utuh, seperti bagian pendahuluan, } \\
\text { isi, penutup, dan simpulan }\end{array}$ \\
\hline Struktur Mikro & $\begin{array}{l}\text { Makna lokal dari suatu teks yang dapat diamati dari pilihan } \\
\text { kata, kalimat, dan gaya yang dipakai oleh suatu teks. }\end{array}$ \\
\hline
\end{tabular}

Tabel 2

Elemen Wacana Teks Van Dijk

\begin{tabular}{|c|c|c|}
\hline $\begin{array}{l}\text { Struktur } \\
\text { Wacana }\end{array}$ & Hal yang Diamati & Elemen \\
\hline Struktur makro & $\begin{array}{c}\text { Tematik } \\
\text { Tema atau topik yang } \\
\text { dikedepankan }\end{array}$ & Topik \\
\hline Super struktur & $\begin{array}{c}\text { Skematik } \\
\text { Bagaimana pendapat } \\
\text { dirangkai dan disusun) }\end{array}$ & Skema atau alur \\
\hline Struktur mikro & $\begin{array}{l}\text { Semantik } \\
\text { Makna yang ingin ditekankan } \\
\text { dalam teks. Misalnya dengan } \\
\text { memberi detail pada satu sisi. }\end{array}$ & $\begin{array}{l}\text { Latar, detail, maksud, } \\
\text { praanggapan, nominalisasi }\end{array}$ \\
\hline Struktur mikro & $\begin{array}{c}\text { Sintaksis } \\
\text { Bagaimana kalimat (bentuk, } \\
\text { susunan) yang dipilih }\end{array}$ & $\begin{array}{l}\text { Bentuk kalimat, koherensi, } \\
\text { kata ganti }\end{array}$ \\
\hline Struktur mikro & $\begin{array}{c}\text { Stilistika } \\
\text { Bagaimana pilihan kata yang } \\
\text { digunakan dalam teks }\end{array}$ & Leksikon \\
\hline Struktur mikro & $\begin{array}{c}\text { Retoris } \\
\text { Bagaimana dan dengan cara } \\
\text { apa penekanan dilakukan }\end{array}$ & Grafis, metafora, ekspresi \\
\hline
\end{tabular}

Sobur (2006:74)

Elemen tematik (tema atau topik) menunjukkan kepada gambaran umum dari suatu teks, disebut juga gagasan inti atau ringkasan. Topik berkaitan dengan apa yang ingin disampaikan oleh penulis kepada pembaca. Elemen skematik berkaitan dengan skema atau alur teks dari mulai pendahuluan sampai dengan simpulan atau akhir. Semantik dapat dikategorikan sebagai makna lokal (local meaning) yaitu makna yang muncul dari hubungan antar kalimat, hubungan antar proposisi yang membangun makna teks. Latar teks berkaitan dengan alasan atau latar belakang kenapa teks ditulis dan tujuan atau maksud dari penulisan teks. Elemen detail berhubungan dengan kontrol informasi yang hendak disampaikan oleh penulis. Informasi mana yang hendak disampaikan dengan detail maksimal dan informasi mana yang hendak disampaikan dengan detail minimal. Praanggapan merupakan pernyataan yang digunakan untuk mendukung makna dari suatu teks.

Elemen sintaksis memuat bentuk kalimat, koherensi, dan kata ganti. Elemen ini berkaitan dengan bagaimana menampilkan diri secara positif dan lawan secara negatif dengan memanfaatkan kalimat. Elemen stilistika (leksikon) berkaitan dengan pemilihan kata yang digunakan oleh penulis dari 
kemungkinan kata yang tersedia. Sedangkan elemen retoris (grafis, metafora, ekspresi) berkaitan dengan bagaimana pesan hendak disampaikan kepada pembaca. Penggunaan grafis, kata-kata metafora, dan ekspresi dalam teks digunakan untuk meyakinkan pembaca atas apa yang disampaikan oleh penulis.

Teks yang akan diungkap dengan menggunakan teori Van Dijk adalah teks syair Nasehat Diniyah yang ditulis oleh Kyai Hasan Qolay. Teks syair ini terdapat pada halaman 51 dan 52 kitab Taudlihus Sholah yang ditulis oleh Kyai Hasan Qolay (KHQ). Kitab ini selesai ditulis pada hari Selasa, 13 Rajab 1355 H (1932 M) di Campang Tiga Kumoring Palembang. Kitab Taudlihus Sholah merupakan kitab fiqih yang berisi tentang kewajiban sholat dan hal-hal yang berkaitan dengan syarat wajib sholat. Kitab ini ditulis dalam aksara Arab Melayu (aksara Arab berbahasa Melayu). Kitab ini memuat 34 pembahasan berkaitan dengan sholat. Teks syair Nasehat Diniyah merupakan pembahasan yang ke-34. Kyai Hasan Qolay merupakan seorang ulama kelahiran Campang Tiga Komering Sumatera Selatan. Beliau merupakan ulama Komering yang mengusai IImu falaq. Karyanya tidak hanya dikenal oleh masyarakat Kumoring tetapi juga masyarakt Jawa (transmigran).

Penelitian terhadap teks ini penting untuk dilakukan mengingat penelitian terhadap naskah yang dihasilkan oleh ulama Kumoring masih sangat jarang sekali dilakukan. Selain itu, penelitian ini dilakukan dalam rangka melestarikan khazanah budaya daerah Kumoring yang saat ini mulai tidak dikenal oleh generasi mudanya.

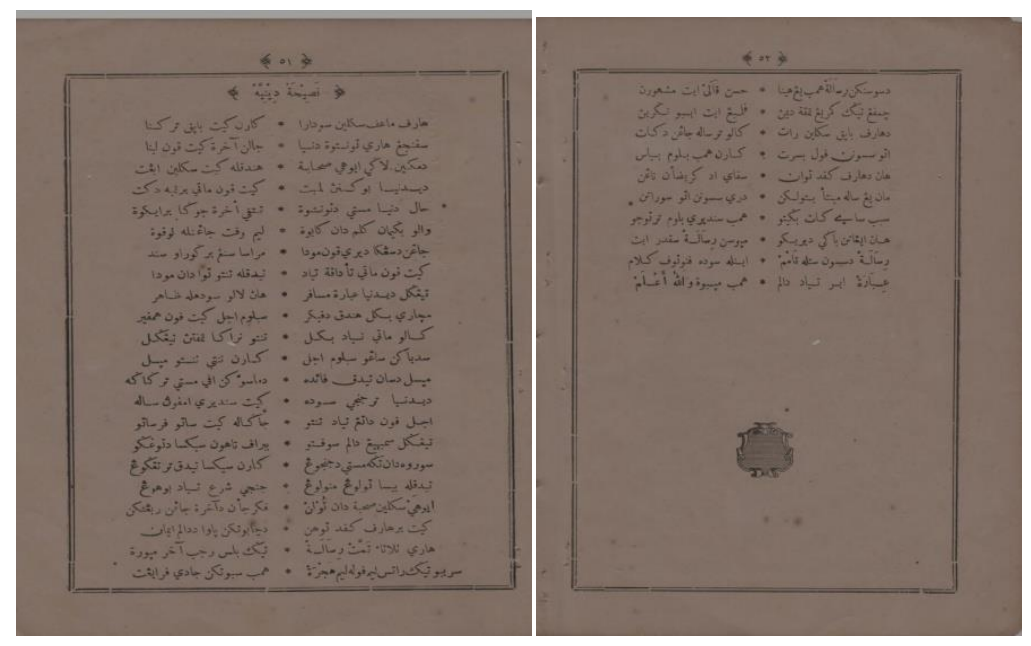

Gambar 1

Teks Syair Nasehat Diniyah KQH

(KHQ,1932:51-52)

Teks syair Nasehat Diniyah (ND) secara umum berisi ajakan untuk mengingat kehidupan akhirat sebab kematian bukan semakin lama datangnya, justru sebaliknya. Ingat akan kehidupan akhirat itu berarti mempersiapkan bekal untuk hidup di akhirat kelak. Bekal yang tepat untuk dibawa ke kehidupan akhirat kelak adalah sholat lima waktu. Dengan menegakkan sholat lima waktu, dapat diartikan bekal untuk hidup di akhirat sudah disiapkan.

Berpikir akan kehidupan akhirat ini harus dilakukan, sebab manusia hidup di dunia ini hanya sebentar, ibarat musyafir, berlalu begitu saja. Sementara kematian bisa datang kapan saja, tidak melihat usia. Jangan sampai kemudian manusia menyesal karena tidak menyiapkan bekal untuk hidup akhirat, yaitu menegakkan sholat. Jika sholat tidak ditegakkan pun demikian dengan perintah dan larangan, tentu di kehidupan akhirat nanti neraka yang akan menjadi tempat tinggalnya. Hal tersebut terjadi karena kesalahan manusia itu sendiri, sebab sebelum manusia kemudian terlahir di dunia, dia sudah terikat janji. Sudah sepatutnya di kehidupan dunia ini, manusia saling mengingatkan akan kebenaran, sebab di akhirat manusia tidak akan bisa saling menolong. Dengan menegakkan sholat harapannya adalah meninggal dalam keadaan selamat. 


\section{DIMENSI TEKS WACANA KRITIS MODEL VAN .... 23 METODE PENELITIAN}

Metode penelitian suatu prosedur kerja yang sistematis, teratur, dan tertib, yang dapat dipertanggungjawabkan secara ilmiah untuk memecahkan suatu masalah (penelitian) guna mendapatkan kebenaran yang objektif (Prastowo, 2011:25). Metode yang digunakan dalam penelitian ini adalah metode kualitatif deskriptif. Penelitian ini bertujuan untuk mendeskripsikan teks syair Nasehat Diniyah (ND) dengan menggunakan teori analisis wacana kritis model Van Dijk yang fokus pada dimensi teks. Teks syair ND terdiri atas dua bagian, yaitu bagian pertama yang berisi nasehat diniyah, yaiitu bait ke-1 sampai dengan bait ke-20, dan bagian ke-2 yang berisi tentang penulisan kitab Taudlihus Sholah dan syair ND. Yang menjadi data pada penelitian ini adalah bagian pertama dari teks syair ND yaitu dari bait ke-1 sampai dengan bait ke-20 dari keseluruhan 32 bait yang ada.

Pengumpulan data dilakukan dengan cara simak dengan teknik lanjutan catat (Mahsun, 2007:9293 ). Data dalam penelitian ini adalah kata-kata dan kalimat yang terdapat pada teks syair Nasehat Diniyah karya KHQ. Proses analisis data menggunakan model Miles and Huberman yang dilakukan secara interaktif dan terus menerus. Komponen dalam analisis data meliputi reduksi data, penyajian data, dan penarikan kesimpulan/verifikasi (Sugiono, 2012:337). Lebih lanjut, data dianalisis menggunakan teori wacana kritis model Teun Van Dijk dengan langkah-langkah berikut. Pertama, deskripsi, yaitu menguraikan strategi wacana yang ada dalam teks . Kedua, interpretasi, yaitu menafsirkan hasil parafrase pada tahap pertama. Ketiga, eksplanasi, yaitu mencari penjelasan atas hasil penafsiran pada tahap pertama dan kedua (Badara, 2012:72).

\section{HASIL DAN PEMBAHASAN}

\section{HASIL}

Secara keseluruhan, berdasarkan analisis tema pada teks syair Nasehat Diniyah (ND), tema pada teks syairu tersebut meliputi dua bagian, yaitu tema kematian, sholat, dan akhirat (tema 1) dan tentang penulisan teks syair Nasehat Diniyah (tema 2). Persebaran kedua tema tersebut pada teks syair ND adalah: pertama, tema 1 terdapat pada teks syair ND mulai dari bait pertama sampai dengan bait ke20. Kedua, tema 2 terdapat pada teks syair mulai dari bait ke-21 sampai dengan bait ke-32. Penelitian ini hanya fokus pada tema pertama, yaitu mulai dari bait ke-1 sampai dengan bait ke-20. Berikut hasil analisis dimensi teks model Van Dijk terhadap teks syair Nasehat Diniyah berkaitan dengan tema pertama.

Tabel 4

Hasil Analisis Dimensi Teks

\begin{tabular}{|c|c|c|}
\hline Struktur Wacana & Elemen & Temuan \\
\hline $\begin{array}{l}\text { Struktur makro } \\
\text { (Tematik) }\end{array}$ & Topik/Tema & $\begin{array}{l}\text { Kematian, Sholat, dan Akhirat (ajakan untuk senantiasa } \\
\text { mengingat akhirat dengan menegakkan sholat sebelum } \\
\text { kematian datang) }\end{array}$ \\
\hline $\begin{array}{c}\text { Super struktur } \\
\text { (Skematik) } \\
\text { Bagaimana } \\
\text { pendapat dirangkai } \\
\text { dan disusun) }\end{array}$ & Skema/Alur & $\begin{array}{l}\text { Pembukaan: permintaan maaf penulis karena mencoba } \\
\text { mengingatkan pembaca ttg kelenaan bersama akan dunia dan } \\
\text { melupakan akhirat (bait 1,2). Semestinya tidak seperti itu, } \\
\text { sebab kehidupan di dunia cuma sebentar sementara kematian } \\
\text { semakin dekat (bait ke-3 dan ke-4). } \\
\text { Isi: Perkara dunia harus dipenuhi, demikian juga dengan } \\
\text { urusan akhirat (bait ke-5), bentuknya adalah tidak } \\
\text { meninggalkan sholat lima waktu dalam kondisi apapun (bait } 6 \text { ), } \\
\text { karena itu, tidak tepat kalau kita terus meras muda yang } \\
\text { senang dengan gurau senda (bait ke-7), sebab kematian } \\
\text { datang tanpa melihat usia (bait ke-8). Hidup di dunia hanya } \\
\text { sebentar seperi musyafir (bait 9), karenanya, harus berfikir } \\
\text { untuk menyiapkan bekal hidup di akhirat sebelum datang } \\
\text { kematian (bait ke-10). Sebab, jika meninggal tidak membawa } \\
\text { bekal, di akhirat kelak neraka menjadi tempat tinggalnya (bait } \\
\text { ke-11). Karenanya, seyogyanya ketika di dunia sudah } \\
\text { menyiapkan bekal untuk kehidupan akhirat, agar tidak terjadi } \\
\text { penyesalan (bait ke-12). Sebab, menyesal itu tidak ada }\end{array}$ \\
\hline
\end{tabular}




\begin{tabular}{|c|c|c|}
\hline & & $\begin{array}{l}\text { gunanya, masuk neraka sudah pasti adanya (bait ke-13). Hal } \\
\text { tersebut karena manusia hidup di dunia sudah terikat janji. } \\
\text { Bagaimanapun manusia jualah yang melakukan kesalahan } \\
\text { (bait ke-14). } \\
\text { Kematian itu bisa datang kapan saja, karenanya hendaknya } \\
\text { manusia menjaga diri masing-masing (bait ke-15), sebab, } \\
\text { sekali saja meninggalkan sholat, ganjarannya adalah siksa } \\
\text { neraka beberapa tahun (bait ke-16). } \\
\text { Melaksanakan kewajiban dan menjauhi larangan harus } \\
\text { ditegakkan, karena manusia tidak akan mungkin menanggung } \\
\text { siksa neraka (bait ke-17). Padahal, pada saat seperti itu } \\
\text { manusia tidak bisa saling menolong sementara apa yang } \\
\text { sudah digariskan oleh syara' pasti terjadi (bait ke-18). } \\
\text { Penutup: Bersebab itu semua, hendaklah manusia tidak } \\
\text { meringankan (melalaikan) kewajiban akan kehidupan akhirat } \\
\text { (bait ke-19) dengan harapan akan meninggal dalam Islam } \\
\text { (husnul khotimah) (bait ke-20). }\end{array}$ \\
\hline \multirow[t]{4}{*}{$\begin{array}{l}\text { Struktur mikro } \\
\text { (Semantik) } \\
\text { Makna yang ingin } \\
\text { ditekankan dalam } \\
\text { teks. Misalnya } \\
\text { dengan memberi } \\
\text { detail pada satu sisi. }\end{array}$} & Latar & $\begin{array}{l}\text { Latar sosial masyarakat Campang Tiga pada saat teks syair } \\
\text { ditulis. Masyarakatnya terindikasi terlena terhadap kehidupan } \\
\text { akhirat karena menuntut dunia (bait ke-1 dan ke-2). Selain itu, } \\
\text { ada masyarakat yang berusia tua merasa terus muda sehingga } \\
\text { lalai akan akhirat dan senang bersenda gurau (bait ke-7). } \\
\text { Masyarakatnya cenderung meringankan urusan akhirat (bait } \\
\text { ke-18) }\end{array}$ \\
\hline & Detail & $\begin{array}{l}\text { Detail dimunculkan dalam bentuk penegasan pada kata-kata } \\
\text { baik dengan menggunakan partikel -pun (bait ke-2, ke- } 4 \text {, ke- } 7 \text {, } \\
\text { ke-8, ke-10, ke-15) atau -lah (bait ke- } 6 \text {, ke-8, bait ke- } 9 \text {, ke-15, } \\
\text { ke-18). Selain itu penegasan juga muncul melalui penggunaan } \\
\text { kata-kata yang bermakna tersebut. Kata-kata penegas yang } \\
\text { ditemukan adalah mesti, walau bagaimana, tentu }\end{array}$ \\
\hline & Maksud & $\begin{array}{l}\text { menyiapkan bekal untuk kehidupan di akhirat sebelum } \\
\text { kematian datang. Bekal yang dimaksud adalah sholat lima } \\
\text { waktu dengan benar dan menegakkan perintah dan larangan. } \\
\text { Tentang kehidupan akhirat } \mathrm{HQ} \text { menyebutnya dalam beberapa } \\
\text { bait syair, yaitu bait ke-2, bait ke- } 5 \text {, bait ke-11, bait ke-13, dan } \\
\text { bait ke-19. Berkaitan dengan kematian, } \mathrm{HQ} \text { juga menyebutnya } \\
\text { beberapa kali dalam syairnya, yaitu pada bait ke-4, bait ke-8, } \\
\text { bait ke-10, bait ke-11, bait ke-15, dan bait ke-20. Sedangkan } \\
\text { ungkapan HQ dalam teks syair berkaitan dengan sholat/ bekal } \\
\text { untuk kehidupan akhirat terdapat pada beberapa bait, yaitu bait } \\
\text { ke- } 6 \text {, bait ke-10, bait ke-12, bait ke-16, dan bait ke- } 17 \text {. }\end{array}$ \\
\hline & Praanggapan & $\begin{array}{l}\text { Karena Kita banyak terkena (bait ke-1), Jalan akhirat Kita pun } \\
\text { lena (bait ke-2), Jangan disangka diripun muda * Merasa } \\
\text { senang bergurau senda (bait ke-7), Kalau mati tiada bekal * } \\
\text { Tentu neraka tempatnya tinggal (bait ke-11), Karena nanti } \\
\text { tentu menyesal (bait ke-12), Beberapa tahun siksa ditunggu } \\
\text { (bait ke-16), Karena siksa tidak tertanggung (bait ke-17), } \\
\text { Tidaklah bisa tolong menolong * Janji syara' tiada bohong (bait } \\
\text { ke-18), Pekerjaan di akhirat jangan ringankan (bait ke-19) }\end{array}$ \\
\hline \multirow[t]{2}{*}{$\begin{array}{c}\text { Struktur mikro } \\
\text { (Sintaksis) } \\
\text { Bagaimana kalimat } \\
\text { (bentuk, susunan) } \\
\text { yang dipilih }\end{array}$} & $\begin{array}{l}\text { Bentuk } \\
\text { Kalimat }\end{array}$ & $\begin{array}{l}\text { Sebagian bait ditulis dengan menggunakan kalimat aktif (harap } \\
\text { maaf, tuntut, lena, ingat, luput, merasa, tak dapat, mencari, } \\
\text { tinggal, sediakan, menyesal, empunya, datang, jagalah, } \\
\text { tinggal, tolong menolong, ringankan, berharap). Sebagiannya } \\
\text { lagi ditulis dalam bentuk kalimat pasif (dituntut, disangka, } \\
\text { terkena, difikir, dimasukkan, tergagah, terjanji, ditunggu, } \\
\text { dijunjung, tertanggung, dicabutkan). Sisanya ditulis dalam } \\
\text { kalimat nominal (dekat, ibarat, hampir, tiada, faidah, bohong). }\end{array}$ \\
\hline & Koherensi & $\begin{array}{l}\text { Bait ke-1 dan } 2 \text { (kata ganti kita), bait ke-3 (kata ganti kita), bait } \\
\text { ke-4 (kata ganti kita), bait ke-5 dan ke-6 dihubungkan } \\
\text { konjungsi walau bagaimana. Bait ke- } 7 \text { dan ke- } 8 \text { dihubungkan } \\
\text { dengan kesamaan tema. Koherensi bait ke-9 dan ke-10 juga } \\
\text { dihubungkan dengan kesamaan tema. Bait ke-11 dan ke-12 } \\
\text { dihubungkan dengan kesamaan tema, yaitu tentang bekal } \\
\text { sebelum ajal. Demikian juga dengan bait ke-13 dan ke-14, } \\
\text { terhubung dengan kesaman tema. Bait ke-15 dan ke-16 juga }\end{array}$ \\
\hline
\end{tabular}


DIMENSI TEKS WACANA KRITIS MODEL VAN $\mid 25$

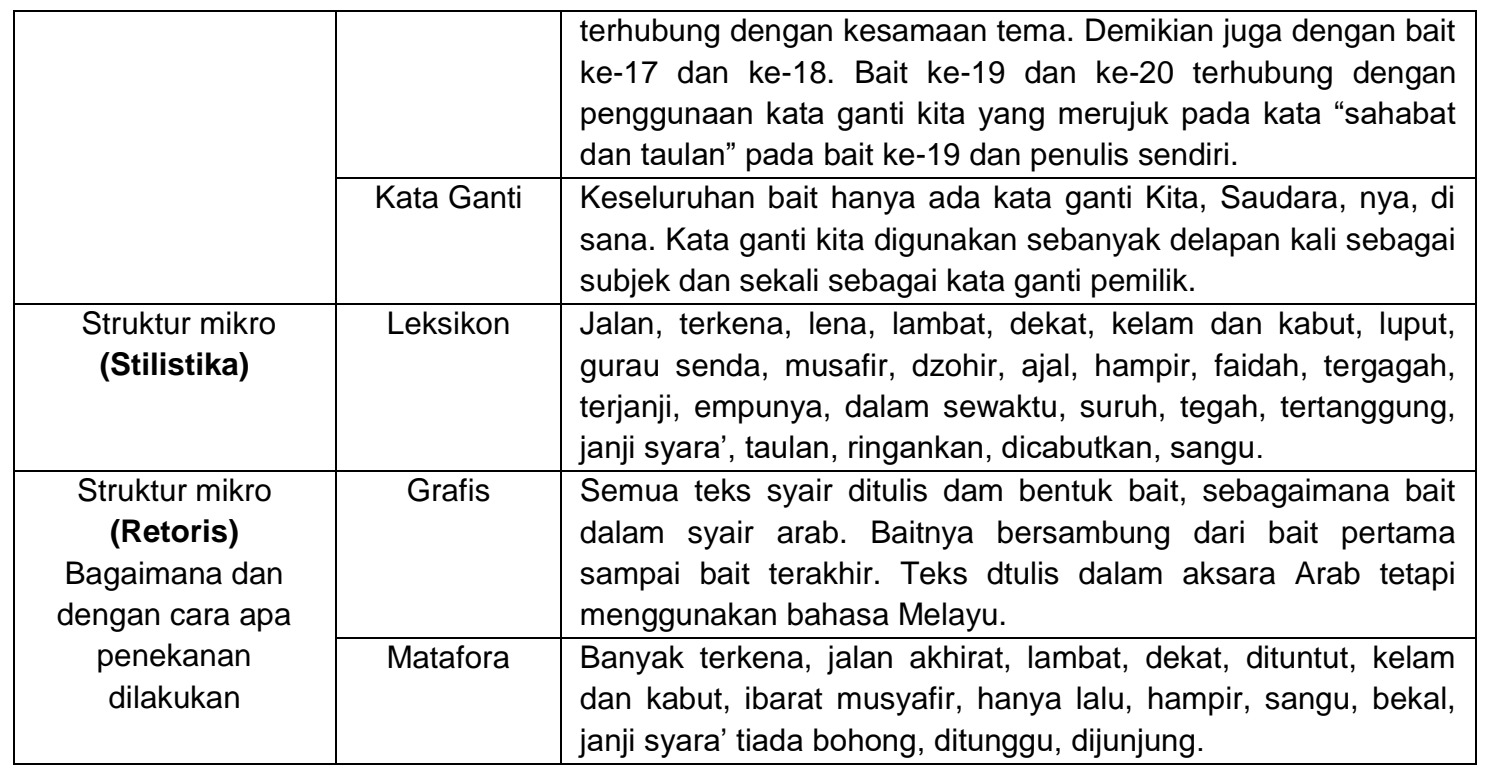

\section{Pembahasan}

Analisis wacana kritis model Van Dijk pada dimensi teks berkaitan dengan analisis terhadap struktur wacana. Analisis tersebut meliputi analisis struktur makro (topik/tema), super struktur (skematik/alur), dan struktur mikro (semantik, sintaksis, stilistika, dan retoris).

1. Analisis Struktur Makro

Analisis struktur Makro berkaitan dengan tema dalam sebuah wacana. Sebagaimana judul teks syair yang ditulis oleh Hasan Qolay, yaitu Nasehat Diniyah, tema yang terdapat pada teks syair tersebut berkaitan erat dengan judul tersebut. Nasehat Diniyah dalam bahasa Indonesia berarti nasehat keagamaan. Tema dalam teks syair $\mathrm{HQ}$ tersebut berkaitan erat dengan nasehat keagamaan, yaitu tentang sholat, kematian, dan akhirat (ajakan untuk senantiasa mengingat akhirat dengan menegakkan sholat sebagai bekal untuk kehidupan di sana). Teks ini jelas menyatakan bahwa bekal yang harus disiapkan untuk kehidupan akhirat adalah sholat (walau bagaimana kelam dan kabut lima waktu janganlah luput-bait ke-6, Tinggal sembahyang dalam sewaktu, beberapa tahub siksa ditunggu-bait ke16). Sholat merupakan bentuk komunikasi manusia dengan Penciptanya. Dalam sholat manusia menghadapkan wajah dan memasrahkan hidupnya semata untuk Tuhannya, dengan tunduk dan sujud. Kepasrahan tersebut diharapkan dapat menimbulkan dampak setelahnya. Sebagai mana dinyatakan dalam ayat al Quran surat Al Ankabut ayat 45 bahwa sesungguhnya sholat itu mencegah dari perbuatan keji dan mungkar, dan bahwa sholat itu lebih utama dari ibadah yang lainnya (Depag Ri, 2002:566). Maka sebenarnya menegakkan sholat dengan sebenarnya sudah otomatis menegakkan perintah dan larangan.

Tema tentang sholat ini memang sesuai dengan pembahasan dalam kitab Taudhihus Sholah yang ditulis oleh $\mathrm{HQ}$ yang membahasa tentang sholat dan segala hal yang berkaitan dengan sholat. Sholat sebagaimana diuraikan oleh $\mathrm{HQ}$ dalam kitabnya tersebut tidak sebatas memenuhi persyaratan sholat aspek formal (terpenuhi syarat dan rukunnya), tetapi juga pemenuhan aspek spiritual yaitu bahwa khusyuk itu menjadi indikator sempurnanya doa. Sebab bacaan dalam sholat juga merupakan serangkaian doa.

Pembicaraan tentang sholat ini dikaitkan dengan bekal untuk kehidupan akhirat. Dari bait ke-2 $\mathrm{HQ}$ telah menyinggung tentang kehidupan akhirat ("sepanjang hari tuntut dunia, jalan akhirat kita pun lena"). Pada bait tersebut, HQ menjelaskan bahwa kita (manusia) karena terlalu sibuk dengan urusan dunia sering lupa akan kehidupan akhirat. Padahal sebagaimana HQ menggunakan kata "jalan", kehidupan dunia dan akhirat merupakan bagian dari fase seluruh perjalanan hidup manusia. Ujung dari perjalan tersebut adalah surga atau neraka.

Berkaitan dengan mempersiapkan bekal tersebut, $\mathrm{HQ}$ beberapa kali mengingatkan akan kesegeraan menyiapkannya bersebab kematian yang tidak tentu kapan datangnya. Jika kematian telah datang, manusia tidak lagi memiliki waktu untuk menyiapkan bekal tersebut. Pada bait ke-3 dan ke-4, HQ mengingatkan pembaca (manusia) bahwa hidup di dunia ini hanya sebentar, sementara mati bertambah dekat waktunya ("hendaklah kita sekalian ingat, di dunia bukannya lambat, kita pun mati bertambah 
dekat"). Pada bait ke-5, HQ kembali menegaskan bahwa manusia juga harus menuntut dirinya untuk kehidupan di akhirat ("hal dunia mesti dituntut, tetapi akhirat juga berikut"). Pada bait yang lain (ke-8) HQ menjelaskan tentang kematian yang pasti datangnya, yang tidak memandang usia ("Kita pun mati tak dapat tiada, tidaklah tentu tua dan muda"). Pada bait selanjutnya, HQ memaparkan bahwa mempersiapkan bekal di akhirat harus dipikirkan sebelum kematian datang ("Mencari bekal hendak dipikir, Sebelum ajal kita pun hampir"). Pada bait selanjutnya, HQ menegaskan hal yang akan dialami manusia di kehidupan selanjutnya jika tidak memikirkan urusan akhirat, yaitu penyesalan dan balasan neraka. Sebagaimana dalam kutipan bait syair berikut "Sediakan sangu sebelum ajal, Karena nanti tentu menyesal (bait ke-12), Menyesal di sana tidak faidah, Dimasukkan api mesti tergagah". Puncak dari peringatan yang disampaikan oleh $\mathrm{HQ}$ adalah bahwa apapun yang terjadi pada manusia kelak, semua semata kesalahan manusia. Maka, sudah seharusnya masing-masing manusia menjaga dirinya sendiri. Meninggalkan sholat sekali waktu saja, balasannya adalah siksa di akhirat selama bertahun-tahun. Penjelasan tersebut sebagaimana kutipan dalam bait ke-13 sampai dengan bait ke-16 berikut.

Menyesal di sana tidak faidah * Dimasukkan api mesti tergagah (bait ke-13)

Di dunia terjanji sudah * Kita sendiri empunya salah (bait ke-14)

Ajal pun datang tiada tentu * Jagalah kita satu per satu (bait ke-15)

Tinggal sembahyang dalam sewaktu * Beberapa tahun siksa ditunggu (bait ke-16).

Hal terakhir berkaitan dengan bekal, kematian, dan akhirat yang diperingatkan oleh $\mathrm{HQ}$ adalah bahwa jika perintah dan larangan sudah ditegakkan manusia dapat berharap kepada Tuhan untuk meninggal dalam keadaan selamat. Meninggal dalam keadaan selamat berarti juga selamat untuk kehidupannya di akhirat. Bagaimanapun, jika manusia tidak menegakkan perintah dan larangan, siksa di akhirat tidak dapat ditanggungnya. Sementara itu, di kehidupan akhirat, manusia tidak bisa saling menolong. Penjelasan tersebut sebagaimana kutipan syair berikut.

Suruh dan tegah mesti dijunjung * Karena siksa tidak tertanggung (bait ke-17)

Tidaklah bisa tolong menolong * Janji syara' tiada bohong (bait ke-18)

Kita berharap kepada Tuhan * Dicabutkan nyawa di dalam iman (bait ke-20)

\section{Analisis Super Struktur}

Analsis super struktur berkaitan dengan skema atau alur. Dalam hal ini analsis fokus pada bagaimana pendapat atau ide itu dirangkai dan disusun. Secara skema atau alur, teks syair ND, disusun dengan urutan pembukaan, isi, dan penutup. Bagian pembuka dari bagian pertama teks syair ini adalah permintaan maaf penulis kepada pembaca karena dengan syairnya tersebut bermaksud mengingatkan pembaca dan diri penulis sendiri akan kehidupan akhirat. Penggunaan kata ganti kita pada bait ke-1 dan ke-2 merujuk pada pembaca dan penulis sendiri. Hal tersebut sebagaimana kutipan syair berikut.

Harap maaf sekalian Saudara \# Karena Kita banyak terkena (bait ke-1)

Sepanjang hari tuntut dunia \# Jalan akhirat Kita pun lena (bait ke-2)

Selanjutnya $\mathrm{HQ}$ menyatakan bahwa seharusnya kita tidak terlena dengan kehidupan dunia, sebab manusia hidup di dunia ini hanya sebentar sementara kematian semakin dekat. Hal tersebut sebagaimana dalam teks syair "... hendaklah kita sekaliang ingat" (bait ke-3), "di dunia bukannya lambat * kita pun mati bertambah dekat" (bait ke-4).

Bagian isi pada bagian pertama dari teks ND berisi tentang nasehat tentang beragama, sebagaimana judulnya. Nasehat agama tersebut berisi tentang bagaimana hendaknya manusia mempersiapkan bekal untuk kehidupan akhirat dengan cara menegakkan sholat. Hal tersebut harus benar-benar menjadi perhatian manusia bersebab kematian bisa datang kapan saja, tidak melihat usia. Secara terperinci, nasehat agama tersebut antara lain: 1) urusan akhirat harus ditunaikan sebagaimana urusan dunia ("hal dunia mesti dituntut * tetapi akhirat juga berikut" (bait ke-5)), 2) wujudnya adalah dengan tidak meninggalkan sholat dalam keadaan apapun ("walau bagaimana kelam dan kabut * Lima waktu janganlah luput" (bait ke-6)), 3) bekal itu harus disiapkan segera agar tidak terjadi penyesalan, sebab menyesal nanti tidak ada gunanya (“... * Karena nanti tentu menyesal", bait ke-12, "Menyesal di sana tidak faidah * ....", bait ke-13), 4) hendaklah manusisa menjaga dirinya masing-masing, sebab kesalahan yang dilakukan semata-mata berasal dari manusia sendiri ("... * Jagalah kita satu persatu", bait ke-15, ".... * Kita sendiri empunya salah", bait ke-14), 5) balasan tidak menegakkan sholat, tidak menegakkan perintah dan larangan adalah neraka ("Tinggal sembahyang dalam sewaktu * beberapa tahun siksa ditunggu", bait ke-16, "Suruh dan tegah mesti dijunjung * Karena siksa tidak tertanggung", bait ke-17), 6) di kehidupan akhirat, manusia tidak bisa saling menolong ("Tidaklah bisa tolong menolong *....", bait ke-18). 
DIMENSI TEKS WACANA KRITIS MODEL VAN .... 27

Bagian penutup $\mathrm{HQ}$ mengajak dan kembali meningatkan agar jangan menganggap remeh urusan akhirat dengan harapan akan meninggal dalam keadaan beriman. Uraian tersebut sebagaimana kutipan syair berikut.

Ayo hai sekalian sahabat dan taulan \# Pekerjaan di akhirat jangan ringankan (bait ke-19)

Kita berharap kepada Tuhan \# Dicabutkan nyawa di dalam iman (bait ke-20)

\section{Analisis Struktur Mikro}

Analisis struktur mikro meliputi tiga bagian, yaitu aspek semantik, berkaitan dengan makna yang hendak ditekankan dalam teks, aspek sintaksis, berkaitan dengan bentuk dan susunan kalimat yang dipilih, aspek stilistika, berkaitan dengan pilihan kata yang digunakan, dan aspek retoris, berkaitan dengan bagaimana dan dengan cara apa penekanan terhadap pesan dilakukan.

a. Analisis Aspek Semantik

Analisis aspek semantik meliputi analisis terhadap latar, detail, maksud, dan praanggapan. Latar merupakan elemen wacana yang dapat menjadi alasan pembenar gagasan yang disampaikan dalam teks. Latar sosial penulisan kitab Taudlihus Sholah yang di dalamnya termaktub syair Nasehat Diniyah adalah desa Campang Tiga di kisaran tahun 1930an. Karena sebagaimana termaktub dalam teks syair bahwa risalah (kitab Taudlihus Sholah) selesai dituliskan pada hari Selasa tanggal 13 Rajab $1355 \mathrm{H}$. Keterangan tersebut sebagaimana kutipan syair berikut:

Hari Selasa tamat risalah \# Tiga belas Rajab akhir menyurah (bait ke-21)

Seribu tiga ratus lima puluh lima hijrah \# Hamba sebutkan jadi peringat (bait ke-22)

Itu berarti risalah tersebut ditulis oleh Hasan Qolay sekitar 89 tahun yang lalu yaitu tahun 1932 Masehi. Maka untuk melihat latar penulisan risalah tersebut, berarti melihat desa Campang Tiga di kisaran tahun 1930-an. Tidak banyak referensi yang bisa dijadikan rujukan untuk melihat secara pasti desa Campang Tiga di kisaran tahun tersebut. Salah satu yang bisa dijadikan rujukan adalah tulisan Dedy Mardiansyah yang dipublikasikan di media online Sahabat Rakyat Komering. Dalam tulisannya Dedy menjelaskan bahwa pada masa $\mathrm{HQ}$, hidup sezaman dengan beliau yaitu Kyai Abbas Husein, $\mathrm{KH}$. Mallawie Husein, dan KH. Shaleh Muzany. Berdasarkan hal tersebut, dapat dikatakan bahwa saat itu, Campang Tiga merupakan salah satu gudang ulama Komering (SRK, Juni 2021).

Kata "lena" dalam bait ke-2 (“...* Jalan akhirat kita pun lena") tidak bermakna terlena yang sebenar-benarnya, yaitu lena dalam artian tidak sama sekali ingat akan kehidupan akhirat. "Lena" dalam teks syair tersebut ungkapan $\mathrm{HQ}$ yang melihat masyarakat desa Campang Tiga saat itu pada dasarnya sudah melaksanakan dan mengerjakan sholat tetapi sebagian dari mereka ada yang keliru dalam memahami syarat, rukun, sunnah dan hal-hal yang membatalkan sholat. Penjelasan ini sebagaimana kutipan berikut:

Adapun kemudian dari pada itu syukurlah sekalian kita kepada Allah Ta'ala boleh dinamakan telah rata-rata memegang dan mendirikan asas agama yaitu sembahyang lima waktu akan tetapi hamba lihat setengah dari pada yang mengerjakan sembahyang itu ada juga yang terkeliru tentang salah suatu dari pada syarat-syaratnya atau salah suatu dari pada rukunrukunnya atau salah suatu dari pada sunnah-sunnahnya atau salah suatu dari pada yang membatalkannya (HQ, 1355H:1).

Demikian juga dengan kutipan syair bait ke-7, ("Jangan disangka diri pun muda * Merasa senang bergurau senda"). Kutipan syair tersebut secara tidak langsung menggambarkan bahwa ada masyarakat yang senang akan senda gurau. Melihat konteks masyarakat Campang Tiga ketika dituliskan risalah kitab tersebut, senang akan gurau senda lebih pada tidak memperhatikan secara terperinci hal-hal yang berkaitan dengan ibadah sholat.

Dengan demikian, penulisan syair dan risalah kitab tersebut dilatarbelakangi oleh kegundahan hati $\mathrm{KH}$. Hasan Qolay akan keberadaan masyarakat lingkungannya yang masih keliru dalam mengerjakan sholat. Teks syair tersebut menjadi semacam peringatan atau pengingat bagi penulis sendiri (HQ) dan masyarakat lingkungannya, juga pembaca syair akan pentingnya mengerjakan sholat dengan sebenarnya, dalam hal ini mengerjakan sholat sesuai dengan madzhab Syafi'i.

Aspek detail dalam memaknai teks syair ini dimunculkan dalam bentuk penegasan pada katakata, baik menggunakan partikel -pun maupun partikel -lah. Kata-kata "kita pun" dalam kutipan syair bait ke-2 ("Jalan akhirat kita pun lena), menegaskan bahwa penulis dan masyarakatnya mengalami yang namanya "lena", yaitu tidak memperhatikan dengan baik akan kehidupan akhirat, yaitu menegakkan sholat dengan sebenarnya. Selain itu kata "kita pun" dalam kutipan syair bait ke-4 ("kita pun mati bertambah dekat") menegaskan bahwa penulis dan masyarakat lingkungannya tidak bisa abai terhadap 
urusan akhirat (sholat lima waktu) sebab kematian jelas semakin dekat. Pada bait ke-7 kata "diri pun" pada kutipan syair "jangan disangka diri pun muda", tidak hanya merujuk pada penulis sendiri, tetapi juga masyarakat lingkungannya. Demikian juga bait ke-8, kata "kita pun" dalam kutipan syair "kita pun mati tak dapat tiada" merujuk pada penulis dan masyarakat lingkungannya, termasuk juga pembaca teks syair.

Kata "ajal pun" dalam kutipan syair bait ke-15 ("ajal pun datang tiada tentu") menegaskan bahwa kematian itu pasti datangnya dan manusia tidak tahu kapan waktu datangnya, maka mengingat dan memperingatkan diri untuk fokus juga akan urusan akhirat merupakan hal yang harus dilakukan.

Beberapa kata dalam bait syair yang menggunakan partikel -lah sebagai bentuk penegasan akan makna yang hendak disampaikan oleh HQ yaitu "hendaklah" (bait ke-3),, "janganlah" (bait ke-6), "tidaklah" (bait ke-8), "sudahlah" (bait ke-9), "jagalah" (bait ke-15), dan "tidaklah" (bait ke-18). Kata "hendaklah" dalam kutipan syair "hendaklah kita sekalian ingat" (bait ke-13) dapat bermakna sudah sepatutnya. Himbauan tersebut ditujukan kepada diri penulis dan masyarakat lingkungannya, termasuk juga dengan pembaca dengan menggunakan kata ganti "kita". "Kita" pada kutipan tersebut diperjelas dengan kata yang mengikutinya yaitu sekalian. Imbauan tersebut berkenaan dengan mengingat akan beberapa hal sebagaimana dalam kutipan syair selanjutnya. Beberapa hal yang dipesankan oleh $\mathrm{HQ}$ untuk diingat antara lain: 1) di dunia hanya sebentar, mati semakin dekat ("Di dunia bukannya lambat * Kita pun mati bertambah dekat”, bait ke-4), 2) urusan akhirat harus ditunaikan (“... * Tetapi akhirat juga berikut", bait ke-5), 3) jangan meninggalkan sholat lima waktu dalam keadaan apapun ("Walau bagaimana kelam dan kabut * Lima waktu janganlah luput", bait ke-6), 4) jangan sampai menyesal di kemudian hari ("Menyesal di sana tidak faidah * ...", bait ke-13), 5) agar masing-masing kita menjaga diri (“... * Jagalah kita satu persatu”, bait ke-15), 6) menegakkan perintah dan larangan ("Suruh dan tegah mesti dijunjung *..., bait ke-17).

Selain penggunaan partikel -lah, detail juga dimunculkan dalam bentuk penegasan dengan menggunakan kata-kata yang bermakna penekanan, yaitu mesti, walau bagaimana, dan tentu. Ketiga kata tersebut menuntut untuk dilakukannya atau menegaskan terjadinya kata kerja setelahnya. Dalam teks syair, kata mesti diikuti oleh kata dituntut dan tergegah. Hal tersebut sebagaimana kutipan syair berikut, "Hal dunia mesti dituntut * Tetapi akhirat juga berikut" (bait ke-5) dan "Menyesal di sana tidak faidah * Dimasukkan api mesti tergegah" (bait ke-13). Bait ke-5 menjelaskan bahwa perkara dunia harus dipenuhi, demikian juga dengan urusan akhirat. Bait ke-13 menjelaskan bahwa penyesalan di akhirat itu tidak ada gunanya, karena ketika masuk neraka pasti tidak sanggup menahannya. Penggunaan kata walau bagaimana (bait ke-6) menegaskan bahwa dalam kondisi apapun manusia tidak boleh meninggalkan sholat. Pemaknaan ini terkait dengan kata-kata setelahnya sebagaimana kutipan syair "walau bagaimana kelam dan kabut * lima waktu janganlah luput" (bait ke-6). Terakhir kata tentu menegaskan bahwa apa yang disebutkan setelahnya pasti akan terjadi. Sebagaimana dalam teks syair, bahwa neraka pasti balasannya bagi orang yang mati tanpa menyiapkan bekal (menegakkan sholat dengan benar) ("Kalau mati tiada bekal * Tentu neraka tempatnya tinggal", bait ke-11).

Aspek maksud berkaitan dengan apa yang secara jelas hendak disampaikan oleh penulis. Dalam teks syair ND, hal pokok yang secara jelas hendak disampaikan oleh $\mathrm{HQ}$ adalah tentang menyiapkan bekal untuk kehidupan di akhirat sebelum kematian datang. Bekal yang dimaksud adalah sholat lima waktu dengan benar dan menegakkan perintah dan larangan. Tentang kehidupan akhirat $\mathrm{HQ}$ menyebutnya dalam beberapa bait syair, yaitu bait ke-2, bait ke-5, bait ke-11, bait ke-13, dan bait ke-19. Berkaitan dengan kematian, $\mathrm{HQ}$ juga menyebutnya beberapa kali dalam syairnya, yaitu pada bait ke-4, bait ke-8, bait ke-10, bait ke-11, bait ke-15, dan bait ke-20. Sedangkan ungkapan HQ dalam teks syair berkaitan dengan sholat/ bekal untuk kehidupan akhirat terdapat pada beberapa bait, yaitu bait ke-6, bait ke-10, bait ke-12, bait ke-16, dan bait ke-17.

Praanggapan berkaitan dengan pernyataan-pernyataan yang mendukung tersampainya pesan yang hendak disampaikan oleh penulis kepada pembaca. Berkaitan dengan syair ND, praanggapan berarti pernyataan dalam teks syair yang mendukung tersampainya pesan yang hendak disampaikan oleh HQ kepada pembaca dan lingkungannya. Pernyataan-pernyataan tersebut sebagaimana dalam kutipan syair berikut.

\footnotetext{
... * Karena Kita banyak terkena (bait ke-1)

... * Jalan akhirat Kita pun lena (bait ke-2)

Jangan disangka diripun muda * Merasa senang bergurau senda (bait ke-7)

Kalau mati tiada bekal * Tentu neraka tempatnya tinggal (bait ke-11)

... * Karena nanti tentu menyesal (bait ke-12)

.. * Beberapa tahun siksa ditunggu (bait ke-16)
}

Dedy Mardiansyah,Yandi, Lailatul Fitriyah 
... * Karena siksa tidak tertanggung (bait ke-17)

Tidaklah bisa tolong menolong * Janji syara' tiada bohong (bait ke-18)

... * Pekerjaan di akhirat jangan ringankan (bait ke-19)

Pernyataan yang teridentifikasi sebagai praanggapan tersebut, mendukung pesan yang hendak disapaikan oleh HQ. Sebagaimana dikemukakan di atas, bahwa HQ melalui syairnya hendak mengingatkan kepada pembaca, lingkungan dan dirinya sendir agar senantiasa ingat untuk menyiapkan bekal bagi kehidupan akhirat sebelum ajal datang. Bekal itu berupa sholat lima waktu yang dilakukan dengan benar. Pernyataan tersebut didukung oleh pernyataan dalam teks yaitu karena kita banyak terkena. Pernyataan ini relevan dengan apa yang hendak disampaikan oleh $\mathrm{HQ}$, bahwa manusia itu punya kecendrungan untuk terkena lupa akan kehidupan akhirat bersebab terlalu asik menuntut dunia. Pernyataan pendukung berikutnya adalah "jangan disangka diri pun muda * merasa senang bergurau senda. Ini menunjukkan bahwa manusia memang perlu untuk diingatkan mengingat umumnya manusia sering merasa terus muda meskipun sudah tua. Selanjutnya adalah pernyataan "kalau mati tiada bekal * tentu neraka tempatnya tinggal. Pernyataan ini menjadi peringatan tegas bahwa kalau manusia mati tanpa membawa bekal untuk kehidupan akhirat, sudah pasti tempatnya nanti adalah di neraka. Karena itulah jangan sampai manusia mengalamii penyesalan di hari kemudian, sebab semua itu tidak ada gunanya. Pernyataan selanjutnya menjadi semacam peringatan yang agak keras, yaitu ketika sholat tidak ditegakkan, siksa akhirat pasti menanti, semantara manusia tidak akan mampu menanggung siksa tersebut. Lebih lanjut lagi, HQ menjelaskan bahwa diakhirat manusia tidak bisa saling menolong, karenanya, sudah sepatutnya manusia itu tidak menggampangkan urusan akhirat.

\section{b. Analisis Aspek Sintaksis}

Analisis aspek sintaksis meliputi analisis bentuk kalimat, koherensi, dan kata ganti. Teks syair ND yang dianalisis yaitu 20 bait syair, masing-masing bait terdiri atas dua bagian yang kedua bagian tersebut seperti pernyataan dan jawaban. Dua puluh bait tersebut terdiri atas 29 kalimat yang meliputi dua bentuk kalimat, yaitu kalimat deklaratif baik aktif maupun pasif, dan kalimat imperatif baik berupa kalimat perintah maupun kalimat larangan. Dari 11 kalimat aktif deklaratif terdapat 4 kalimat yang merupakan kalimat negatif. Sisanya adalah kalimat positif. Kalimat pasif deklaratif sebanyak 7 kalimat. Sedangkan kalimat imperatif perintah sebanyak 4 kalimat, kalimat imperatif larangan sebanyak 3 kalimat. Kalimat-kalimat tersebut ada yang berbentuk kalimat tunggal dan ada yang berbentuk kalimat majemuk. Selain kalimat verbal, beberapa syair ND terbentuk dari kalimat nominal dan adjektifal.

Kalimat nominal dan adjektifal terdapat pada kutipan syair berikut:

"Di dunia bukannya lambat *..." (bait ke-4)

"Tinggal di dunia ibarat musyafir * hanya lalu sudahlah dohir" (bait ke-9)

"Menyesal di sana tidak faidah *..." (bait ke-12)

“... * Janji syara' tiada bohong" (bait ke-18)

Tiga kutipan syair bait ke-4, ke-9, dan ke-12 merupakan bentuk kalimat nominal, sedangkan kutipan syair bait ke-18 merupakan bentuk kalimat adjektifal.

Penggunaan bentuk-bentuk kalimat tertentu dalam bait syair ND memunculkan konotasi tertentu terkait bagaimana $\mathrm{HQ}$ menyampaikan maksudnya melalui syair tersebut. Syair ND dibuka dengan kalimat "Harap maaf sekalian Saudara". Kalimat tersebut merupakan kalimat imperatif berupa perintah yang perintah ini disampaikan dengan cara halus, wujudnya adalah permintaan maaf penulis kepada saudara. Saudara yang dimaksud dalam teks tersebut adalah masyarakat lingkungan $H Q$, tempat ditulisnya teks tersebut. Bentuk serupa dijumpai pada bait selanjutnya, yaitu hendaklah kita. Kalimat "hendaklah kita" juga merupakan bentuk kalimat perintah yang disampaikan secara halus. Di sisi lain, kalimat larangan dengan menggunakan kata janganlah dan jangan disampaikan dengan cara yang tegas.

Secara umum, bentuk kalimat aktif dan pasif dalam syair ND digunakan untuk memaparkan halhal terkait akhirat, mati, dan sholat. Demikian juga dengan kalimat nominal maupun kalimat adjektifal. Meskipun bentuknya adalah kalimat deklaratif, tapi pada dasarnya pada kalimat-kalimat tersebut termuat informasi yang isinya adalah peringatan. Sebagai contoh kutipan syair "di dunia bukannya lambat * kita pun mati bertambah dekat" (bait ke-4). Pada kalimat tersebut ada yang perlu ditambahkan untuk memudahkan pemaknaan, yaitu dengan menambahkan kata "hidup" sebelum kata "di dunia". Sehingga, jika seperti itu kedua bagian bait syair tersebut berbentuk kalimat deklaratif yang bermaksud menyampaikan informasi bahwa hidup di dunia tidak lama dan informasi bahwa kematian kita semakin dekat datangnya. Jika dikaitkan dengan bait sebelumnya, nampak bahwa bait ke-4 tersebut tidak 
sebatas memberikan informasi, tetapi lebih pada memberi peringatan kepada pembaca tentang hidup di dunia dan kematian. Demikian juga dengan bait-bait selanjutnya yang ditulis baik dalam bentuk kalimat deklaratif.

Hasil analisis terkait bentuk kalimat tersebut relevan dengan pesan yang hendak disampaikan oleh $\mathrm{HQ}$ melalui syair ND, yaitu mengingatkan kepada manusia agar mempersiapkan bekal untuk kehidupan akhirat.

Hasil analisis berkaitan dengan koherensi, ditemukan bahwa koherensi antar bait dalam baitbait syair ND dibangung dengan menggunakan kata ganti, konjungsi, dan kesamaan tema. Penggunaan kata ganti yaitu kata ganti "kita" terdapat pada bait ke-1, ke-2, ke-3, dan ke-4. Kata ganti "kita" pada teks syair tersebut merujuk pada orang yang sama yaitu penulis, masyarakat lingkungan, dan pembaca syair. Penggunaan konjungsi sebagai sarana koherensi terdapat pada bait ke-5 dan ke-6. Konjungsi yang digunakan sebagai sarana membangun koherensi yaitu demikianlah dan walau bagaimana. Sedangkan kesamaan tema sebagai sarana kohesi digunakan hampir pada sebagian besar bait syair. Secara keseluruhan, mulai dari bait ke-1 sampai dengan bait ke-20 pada dasarnya apa yang hendak disampaikan oleh $\mathrm{HQ}$ saling terkait, yaitu berkaitan dengan urusan akhirat, kematian, dan bekal sebelum mati. Bait ke-2 berbicara tentang keterlenaan manusia akan kehidupan akhirat. Hal ini berkait dengan bait ke-1, bahwa manusia banyak terkena lupa akan kehidupan akhirat sebagai akibat dari terlalu banyak menuntut dunia. Bait ke-3 menyambung bait ke-2, karenanya hendaklah manusia ingat akan apa yang dinyatakan oleh $\mathrm{HQ}$ dalam bait berikutnya (ke-4) yaitu bahwa hidup di dunia sebentar sementara kematian semakin dekat. Bait ke-5, kembali HQ berbicara tentang akhirat, bahwa sebagaimana dunia, kebutuhan akan hidup di akhirat juga mesti ditunaikan. Wujud menunaikan itu, sebagaimana diungkapkan pada bait ke-6, adalah bagaimanapun keadaan manusia, sholat lima waktu tidak boleh dilalaikan. Bait ke-7 dan ke-8 merupakan satu rangkaian bahwa manusia tidak boleh merasa muda sehingga lupa bahwa mati bisa datang kapan saja. Bait ke-9 masih merupakan lanjutan dari bait ke-8. Manusia tidak bisa lupa bahwa mati bisa datang sewaktu-waktu, sebab manusia tinggal di dunia ini hanya sebentar sebagaimana musyafir. Karenanya, mencari bekal untuk kehidupan akhirat sudah sepatutnya dipikirkan sebelum kemudian kematian datang. Pernyataan ini merupakan lanjutan dari bait sebelumnya.

Bait ke-10 dan ke-11 diikat oleh penggunaan kata "bekal" pada kedua bait tersebut. Bait ke-11 menyatakan bahwa jika bekal tidak dimiliki pada saat kematian datang, nerakalah yang akan menjadi tempat tinggalnya. Kedua bait ini, disamping terikat oleh penggunaan kata "bekal", kesamaan tema yang hendak disampaikan juga mengikat keduanya. Tema yang coba diangkat adalah tentang bekal, mati, dan akhirat. Bait ke-12 koheren dengan bait sebelumnya dengan adanya kata "sangu" yang merupakan padanan kata bekal. Bait ke-12 dan ke-13 dihubungkan oleh pengulangan kata "menyesal" yang disebutkan pada kedua bait tersebut. Bait ke-13 dan ke-14 dihubungkan dengan keterkaitan maksud antara kedua bait tersebut. Yaitu bahwa manusia masuk neraka disebabkan oleh kesalahan manusia itu sendiri. Hal tersebut sebagaimana kutipan syair “... * Kita sendiri empunya salah" (bait ke-14).

Bait ke-15 penulis kembali berbicara tentang kematian yang bisa datang kapan saja, karenanya, sudah semestinya manusia menjaga dirinya masing-masing. Bait ini terkait dengan bait berikutnya dengan pernyataan tersirat bahwa bentuk menjaganya adalah dengan melaksanakan sholat lima waktu dengan istiqomah (terus-menerus). Bait ke-17 merupakan penegasan terhadap bait ke-16, yang secara tidak langsung menyatakan bahwa melaksanakan sholat merupakan bagian dari menegakkan perintah dan larangan. Bait ke-18 secara makna berkait dengan bait ke-17 yaitu bahwa siksa di akhirat kelak sudah pasti adanya, dan manusia tidak bisa saling menolong pada saat itu. Bait ke-19 dan ke-20 merupakan penutup sekaligus harapan dari semua hal yang telah diuraikan oleh $\mathrm{HQ}$ pada bait-bait sebelumnya. Penutup dari uraian pada bait-bait sebelumnya berupa ajakan untuk tidak menggampangkan urusan akhirat. Harapannya adalah agar kita manusia oleh Allah dicabut nyawanya dalam keadaan iman. Kedua bait tersebut juga terhubung oleh penggunaan kata ganti kita yang merujuk pada kata "sahabat dan taulan" dan penulis sendiri.

Berdasarkan analisis kata ganti, ditemukan bahwa kata ganti yang ada dalam teks syair ND antara lain: kita, saudara, -nya, dan di sana. Kata ganti "kita" terdapat pada bait ke-2, bait ke-3, bait ke-4, bait ke-8, bait ke-10, bait ke-14, bait ke-15, dan bait ke-20. Penggunaan kata ganti "kita" pada bait-bait tersebut menempati tiga posisi yang berbeda dalam struktur kalimat bait. Dari 8 kata ganti "kita" enam diantaranya menduduki posisi subjek (kita banyak terkena-B1, kita pun lena-B2, kita sekalian ingat-B3, kita pun mati-B4, kita pun mati-B8, kita sendiri empunya-B14, kita berharap-B20), satu diantaranya menduduki posisi objek (jagalah kita-B15), dan sisanya menjadi kata ganti milik (sebelum ajal kita pun- 
DIMENSI TEKS WACANA KRITIS MODEL VAN .... $\mid 31$ B10). Kata ganti "kita" dalam kajian prononima merujuk pada pembicara dan pendengar. Karenanya, dalam syair ND, kata ganti "kita" merujuk pada penulis (pembicara), masyarakat lingkungannya, dan pembaca (sebagai pendengarnya). Berdasarkan hal tersebut, dapat dinyatakan bahwa melalui syair ND, $\mathrm{HQ}$ bermaksud tidak hanya memberikan peringatan bagi masyarakat lingkungannya, tetapi juga peringatan untuk dirinya sendiri. Hal ini relevan dengan bagian kedua dari rangkaian bait syair tersbut yang menyebutkan bahwa syair itu ditulis sebagai peringatan bagi diri HQ sendiri. Sebagaimana kutipan syair berikut. "Hanya ingatan bagi diriku * menyusun risalah sekedar itu" (bait ke-30).

Kata ganti "saudara" merupakan bentuk pronomina sapaan yang sepadan dengan kata "kamu", yaitu pendengar. Dalam syair tersebut saudara di situ merujuk pada orang banyak karena ada kata "sekalian" sebelum kata "saudara". Kata ganti "-nya" umunya menggantikan milik bagi orang ketiga. Tetapi pada bait ke-4 kata tersebut hanya berfungsi sebagai penegas kata setelahnya. Karenanya, kata ganti tersebut tidak merujuk kepada apa atau siapa. Terakhir adalah kata ganti "di sana" yang merupakan kata ganti penunjuk untuk menyatakan tempat yang agak jauh dari pembicara (KBBI daring). Dalam syair ND, kata "di sana" merujuk pada akhirat. Pemaknaan ini muncul karena bagian kedua bait syair tersebut menyebut tentang api yang konotasinya adalah api neraka. Pun demikian jika melihat pada bait sebelumnya (bait ke-12) yang menyebutkan tentang ajal.

\section{A. Analisis Aspek Stilistika}

Analisis aspek ini berkaitan dengan leksikon yaitu pilihan kata yang seperti apa yang digunakan oleh penulis untuk mewakili gagasannya. Berdasarkan analisis leksikon, ditemukan bahwa beberapa bentuk kata arkais digunakan. Seperti kata "tegah" (cegah), dzohir (jelas), faidah (manfaat), dan taulan. Kata-kata tersebut sekarang ini sudah jarang digunakan. Beberapa kata tersebut menunjukkan perngaruh bahasa Arab terhadap bahasa Melayu saat itu. Kata dzohir dan faidah berasal dari bahasa Arab yang berarti jelas dan manfaat.

Selain itu, bentuk tiada, ajal kita pun hampir, terjanji, empunya, tertanggung, pekerjaan, dicabutkan nyawa, merupakan bentuk-bentuk sangat jarang dijumpai saat ini. Tiada digantikan kata tidak ada. Terjanji bermakna sesuatu yang sudah dijanjikan. Empunya merupakan bentuk lain dari mempunyai. Pilihan kata "dituntut" pada kutipan bait "hal dunia wajib dituntut" menekankan akan pentingnya mengurus urusan dunia dan akhirat. Demikian juga dengan kata "bekal" yang juga diungkapkan dengan kata "sangu". Kedua kata tersebut bermakna sama yaitu sesuatu yang disediakan untuk digunakan dalam perjalanan. Sangu merupakan kata yang berasal dari bahasa Jawa, bekal merupakan bentuk bahasa Indonesianya.

\section{B. Analisis Aspek Retoris}

Analisis aspek ini berkaitan dengan bagaimana dan dengan cara apa penekanan dilakukan. Analisis aspek ini meliputi analisis grafis dan metafora. Secara grafis dijumpai bahwa bait syair ND ditulis tidak sebagaimana syair umumnya yang ditulis dalam empat baris. Bait syair ND ditulis dalam aksara Arab atau dikenal dengan tulisan Jawi dan berbahasa Melayu. Bait syair disusun sebagaimana bait syair dalam bahasa Arab, yaitu dalam satu bait terdapat dua bagian dan bait-bait syair ditulis secara berurutan mulai dari bait pertama sampai terakhir tanpa jeda. Penulisan syair sebagaimana teks syair ND menunjukkan bahwa pengaruh Arab sangat kental pada diri penulis syair, yaitu Hasan Qolay. Hal ini selaras dengan fakta bahwa HQ pernah menuntut ilmu dan bermukim di Makkah selama 17 tahun. Tentu juga penulisan risalah kitab yang di dalamnya terdapat syair ND relevan dengan keberadaan beliau sebagai ulama pada masa itu.

Berkaitan dengan analisis aspek metafora, beberapa bentuk metafora ditemukan dalam bait-bait syair ND. Ungkapan metaforis tersebut antara lain: jalan akhirat, di dunia bukannya lambat, kelam dan kabut, hanya lalu sudahlah dohir, dan kalau mati tiada bekal tentu neraka tempatnya tinggal. Ungkapan jalan akhirat tidak dimaknai jalan tempat orang berjalan atau berkendara, jalan di situ dimaknai sebagai arah menuju satu fase kehidupan yang harus dilalui oleh manusia yaitu akhirat. Untuk sampai pada kehidupan akhirat yang bahagia, manusia harus mempersiapkan bekalnya, yaitu sholat lima waktu.

Ungkapan "di dunia bukannya lambat" (bait ke-4) menggambarkan seolah dunia itu seperti waktu yang berjalannya lambat. Bukannya lambat berarti tidak lambat (cepat). Bait tersebut dapat dimaknai bahwa kehidupan di dunia cepat atau singkat. Ungkapan kelam dan kabut bukan dalam artian suasana alam yang kelam dan berkabut, tapi lebih pada kondisi manusia yang tidak jelas. Dalam hal ini menegakkan sholat lima waktu dengan masih banyak keliru. Berikutnya ungkapan "hanya lalu sudahlah dohir" (bait ke-9) bermakna bahwa kehidupan di dunia itu sudah jelas akan berlalu begitu saja, seperti seorang musyafir. Terakhir ungkapan "kalau mati tiada bekal * tentu neraka tempatnya tinggal" (bait ke11), kata bekal dalam bait tersebut tidak dimaknai bekal dalam arti materi, tapi dimaknai secara 


\section{PENUTUP}

Berdasarkan hasil analisis dapat dinyatakan bahwa dimensi teks model analisis wacana kritis Van Dijk pada teks syair Nasehat Diniyah (ND) pada analisis aspek struktur makro (tematik) dapat dikemukakan bahwa tema syair ND adalah ajakan untuk senantiasa mengingat akhirat dengan menegakkan sholat sebelum kematian datang. Pada analisis super struktur (skematik) ditemukan bahwa teks syair ND terdiri dari pembukaan, isi, dan penutup. Teks syair diawalai dengan bait pembuka yang berupa permintaan maaf dari penulis. Pada bagian isi, teks syair berisi bait-bait tentang anjuran untuk senantiasa mengingat akhirat dengan cara senantiasa menjaga sholat lima waktu. Selain itu pada bagian ini penulis juga mengungkapkan peringatan akan datangnya kematian yang bisa muncul kapan saja. Pada bagian penutup, penulis syair menegaskan tentang kewajiban untuk menegakkan perintah dan menghindari larangan dalam agama dengan harapan Tuhan akan memberikan pungkasan kehidupan yang baik (meninggal dalam keadaan khusnul khotimah). Pada bagian unsur struktur mikro, latar penulisan teks syair adalah masyarakat desa Campang Tiga. Desa Campang Tiga merupakan tempat syair ND ditulis oleh Ky. Hasan Qolay.

Secara keseluruhan analisis teks syair menggunakan dimensi teks model Van Dijk memberikan gambaran tersendiri terhadap hasil pembacaan teks. Terlebih jika analisis ini dilanjutkan pada kedua dimensi model Van Dijk yang lain, tentu hasil eksplorasi terhadap teks akan lebih maksimal.

\section{UCAPAN TERIMAKASIH}

Ucapan terima kasih peneliti sampaikan kepada STKIP Nurul Huda dan TIM Peneliti.

\section{DAFTAR PUSTAKA}

Badara, Aris. 2012. Analisis Wacana: Teori, Metode, dan Penerapannya pada Media. Jakarta: Kencana Prenada Media Group.

Chaer, Abdul. 2012. Pengantar Linguistik Umum. Jakarta: Rineka Cipta.

Darma, Yoce Aliya. 2009. Analisis Wacana Kritis. Bandung: Yrama Widya.

Departemen Agama RI. 2002. Al Qur’an dan Terjemahnya. Semarang: PT. Karya Toha Putra.

Eriyanto. 2011. Analisis Wacana: Pengantar Analisis Teks Media.

Humaira, Hera Wahdah. 2018. Analisis Wacana Kritis (AWK) Model Teun A. Van Dijk pada Pemberitaan Surat Kabar Republika. Jurnal Literasi Vol. 2 Nomor 1

Kridalaksana, Harimurti. 2008. Kamus Linguistik Edisi Keempat. Jakarta: Gramedia Pustaka Utama.

Mahsun. 2007. Metode Penelitian Bahasa; Tahapan Strategi, Metode, dan Tekniknya. Jakarta: PT Raja Grafindo Persada.

Mardiansyah, Dedy. Kiai Haji Hasan Qolay: Tokoh Literasi Kitab Kuning Komering. Dalam media online Sahabat Rakyat Komering. Juni 2021. https://komering.sahabatrakyat.com/daerah/ogan-komeringulu-timur/kiai-haji-hasan-qolay-tokoh-literasi-kitab-kuning-komering/

Moleong, Lexy. 2017. Metodologi Penelitian Kualitatif. Bandung: PT Remaja Rosdakarya.

Qolay, Hasan. 1932. Taudhihussholah. Palembang: Matbaah Al Ahmadiyah.

Sobur, Alex. 2012. Analisis Teks Media: Analisis Wacana, Analisis Semiotik, Analisis Framing. Bandung: Remaja Rosdakarya.

Sugiyono. 2012. Metode Penelitian Pendidikan Pendekatan Kuantitaif, Kualitatif, dan R\&D. Bandung: Alfabeta. 